\title{
The Role of Magnetic Resonance Imaging in the Differential Diagnosis of Giant Rectal and Perirectal Masses
}

\author{
Dev Rektal ve Perirektal Kitlelerin Ayırıcı Tanısında Manyetik Rezonans \\ Görüntülemenin Rolü
}

(1) Fatma Kulalı1, (10 Özgül Düzgün²

1University of Health Sciences Ümraniye Training and Research Hospital, Clinic of Radiology, İstanbul, Turkey

2University of Health Sciences Ümraniye Training and Research Hospital, Clinic of General Surgery, İstanbul, Turkey

\begin{abstract}
Introduction: Our purpose was to depict some specific qualitative and quantitative magnetic resonance imaging (MRI) and diffusion weighted imaging (DWI) findings in differential diagnosis of huge tumors of rectum and perirectal region.

Methods: A total of 81 patients who had $\geq 5 \mathrm{~cm}$ huge tumors of rectum and perirectal region [36 (44\%) women and 45 (56\%) men] with a mean age of $54 \pm 15$ (standard deviation) were enrolled in this retrospective study. Pre-operative MRI with DWI examinations of patients were reviewed by an experienced radiologist. Qualitative (signal intensity, contrast enhancement pattern, the existence of lymphadenopathy and metastasis) and quantitative imaging findings were statistically analyzed according to histopathological results.
\end{abstract}

Results: Of 81 huge tumors of rectum and perirectal region, 60 were malignant and 21 were benign. Among $(n=60)$ malignant tumors, there were 48 rectal adenocancers, two prostate adenocancers, three leiomyosarcomas, three ovarian cancers and four rectal gastrointestinal stromal tumors (GISTs). All rectal GISTs $(n=4)$ showed peripheral heterogeneous arterial enhancement and had hypointense peripheral components whereas central components were more heterogeneous and iso-/hyper-intense on T2-weighted sequences. Most of rectal adenocancers (41/48, 85\%) showed significant enhancement. Lymphadenopathy, invasion and far metastasis were only observed in malignant tumors. Mean "apparent diffusion coefficient" (ADC) ratios of malignant tumors $(0.56 \pm 0.10)$ were significantly lower than those of benign tumors $(0.95 \pm 0.21)$ $(\mathrm{p}<0.05)$.

Conclusion: Specific MRI findings combining with ADC ratio estimation can be helpful for differential diagnosis of bulky rectal and perirectal tumor, and appropriate management of patient.

Keywords: Gastrointestinal stromal tumor, magnetic resonance imaging, rectal cancer, diffusion weighted imaging öz

Amaç: Dev rektal ve perirektal bölge kitlelerinin ayırıcı tanısında önemli olabilecek bazı spesifik kalitatif ve kantitatif manyetik rezonans görüntüleme (MRG) ve difüzyon ağırlıklı görüntüleme (DAG) bulgularını tanımlamayı amaçladık.

Yöntemler: Bu retrospektif çalıșmada, pre-operatif MRG ve DAG tetkikinde rektal ve perirektal bölgede $\geq 5 \mathrm{~cm}$ kitlesi olan toplam 81 hasta [36 (\%44) kadın ve 45 (\%56) erkek] yer aldı. Ortalama yaș $54 \pm 15$ (standart sapma) idi. Pre-operatif MRG ve DAG tetkikleri abdominal görüntüleme konusunda tecrübeli bir radyolog tarafından tekrar değerlendirildi. Kalitatif (sinyal intensiteleri, kontrastlanma paterni, lenfadenopati ve metastaz varlığı) ve kantitatif görüntüleme bulguları ile histopatolojik sonuçlar arasındaki ilişki istatistiksel olarak incelendi.

Bulgular: Çalışmamızda yer alan toplam 81 hastada, 60 malign ve 21 benign dev rektal ve perirektal kitle mevcuttu. Malign kitleler $(n=60)$ içinde, 48 rektal adenokanser, iki prostat adenokanser, üç leiomyosarkom, üç over kanseri ve dört rektal gastrointestinal stromal tümör (GIST) mevcuttu. Tüm rektal GIST'lerde $(n=4)$ arteryal fazda başlayan periferik heterojen kontrastlanma izlendi ve T2- ağılıklı sekanslarda santral kesimleri heterojen, izo-hiperintens seçilirken periferik kesimlerinde hipointens sinyal özellikleri saptandı. Rektal adenokanserlerinin çoğunda $(41 / 48, \% 85)$ yoğun kontrastlanma mevcuttu. Lenfadenopati, komşu organ invazyonu ve uzak metastaz sadece malign kitlelerde izlendi. Ortalama "apparent diffusion coefficient" (ADC) oranları, malign kitlelerde $(0,56 \pm 0,10)$ benign kitlelere $(0,95 \pm 0,21)$ göre anlamlı derecede düşüktü $(p<0,05)$.

Sonuç: Spesifik MRG özellikleri ve ADC oran ölçümlerinin birlikte değerlendirilmesi, dev rektal ve perirektal kitlelerin ayırıcı tanısında önemli bir role sahiptir ve hasta tedavisini planlamada yol göstericidir.

Anahtar Kelimeler: Gastrointestinal stromal tümör, manyetik rezonans görüntüleme, rektal kanser, difüzyon ağırlıklı görüntüleme 


\section{Introduction}

Giant tumors located in the rectal and perirectal regions cause compression and distortion in normal anatomic structures, so it may be difficult to determine the origin of the tumor and decide the correct diagnosis and treatment (1-6). Masses such as rectal adenocarcinoma, sarcoma, neuroendocrine tumor, leiomyoma, ovarian mass, rectal gastrointestinal stromal tumor (GIST), prostate adenocarcinoma, lymphoma, neurogenic tumor and congenital cyst should be considered in the differential diagnosis of giant rectal and perirectal tumors (6). Although rectoscopy-guided biopsy is the most important method for diagnosis, it is insufficient to evaluate intramural and extramural extension of the mass $(1,5)$. Pre-operative imaging is necessary to determine the location of the mass (submucosal/intramural/extramural) and its extension, to evaluate the need for surgical approach to the patient and to decide the surgical technique to be applied (1-7). Computed tomography (CT) and magnetic resonance imaging (MRI) are used in the diagnosis and evaluation of rectal and perirectal tumors (17). MRI is more appropriate because it does not contain radiation and has high soft tissue resolution (1-5). Diffusion-weighted imaging (DWI) may also provide important findings in use with MRI (8-10).

To the best of our knowledge, there is no detailed study in the literature regarding MRI and DWI characteristics that may help in the differential diagnosis of giant rectal and perirectal tumors. Therefore, we aimed to identify some specific qualitative and quantitative MRI and DWI findings that may be important in the differential diagnosis of giant rectal and perirectal masses.

\section{Methods}

Written consent was obtained from the patients and approval was obtained from the ethics committee in accordance with the Helsinki Declaration Criteria before the initiation of study (University of Health Sciences, Ümraniye Training and Research Hospital Ethics Committee of Clinical Studies, decision no: 235, date: 23/01/2019). Lower abdominal MRI reports performed in a single center between January 2014 and January 2019 were reviewed for rectal and perirectal masses using hospital information system. MRI examinations of patients with $\geq 5 \mathrm{~cm}$ rectal and perirectal masses were detected retrospectively. Patients without histopathological diagnosis $(n=15)$ and patients with incomplete or inadequate MRI examination for evaluation $(n=7)$ were excluded. Eighty-one patients ( 36 female, $44 \%$ and 45 male, 56\%) with $\geq 5 \mathrm{~cm}$ mass in the rectal and perirectal region and pre-operative MRI and DWI were included in our study. The mean age was $54 \pm 15$ years.

Contrast-enhanced lower abdominal MRI examinations were performed using a 1.5 Tesla MRI (Magnetom Avanto ${ }^{\circledR}$, Siemens Healthineers, Erlangen, Germany). The contrast-enhanced lower abdominal MRI parameters were: sagittal T2-weighted turbo spin-echo (TSE) BLADE (TR/TE: 5000/112 ms, FOV: 350, matrix: 256×256, section thickness, 7 $\mathrm{mm}$ ), coronal fat-suppressed T2-weighted TSE BLADE (TR/TE: 4000/84 ms, FOV: 320, matrix, 256 $\times 320$, section thickness, $5 \mathrm{~mm}$ ), axial T2weighted fast spin-echo sequence (TR/TE: 3700/88 ms, FOV: 320, matrix: $182 \times 320$, section thickness, $5 \mathrm{~mm}$ ), pre-contrast and post-contrast axial T1-weighted 3D VIBE ( TR/TE: 4.5/2.1 ms, FOV: 380, matrix: 195×320, deflection angle, $15{ }^{\circ} \mathrm{C}$ section thickness, $5 \mathrm{~mm}$ ), diffusion weighted single shot echo planar imaging with b values 0 and $1000 \mathrm{~s} / \mathrm{mm}^{2}$ (FOV: 430, TR/TE: 5200/58, matrix: 115×192, section thickness: 5 mm, NEX: 3).

Pre-operative MRI and DWI examinations were re-evaluated by a radiologist (F.K.) experienced in abdominal imaging who was blinded to the histopathological information of the patients. Longest diameter $(\mathrm{mm})$ of the masses, contour characteristics (regular/irregular), signal intensity characteristics (hypo-, iso-, hyper-intense) in T1- and T2weighted sequences, contrast patterns (mild/intense, homogeneous/ heterogeneous), tumor content (hemorrhagic signal, cystic component), invasion, lymphadenopathy and metastasis were noted. In addition, the apparent diffusion coefficient (ADC) values and ratios of the masses were calculated. For ADC calculation, circular region of interest (ROI) measurements ranging from approximately 100 to $200 \mathrm{~mm}^{2}$ were used. It was ensured that no lumens and extra-mass structures entered into the ROI. ROI measurements were performed in three different locations in the mass and gluteus maximus muscle in the same section. The ratio of the ADC value of the mass to the ADC value of the muscle (ADC ratio) was calculated for the standardization with the obtained mean ROI measurements.

\section{Statistical Analysis}

All patients had histopathological results. The relationship between qualitative (signal intensities, contrast enhancement pattern, presence of lymphadenopathy and metastasis) and quantitative imaging findings and histopathological results were statistically analyzed. The suitability of the parameters to normal distribution was evaluated by ShapiroWilk test. The Mann-Whitney $U$ test was used for the comparison of the quantitative data and the chi-square test was used for the comparison of the qualitative data. Significance was evaluated at $p<0.05$.

\section{Results}

In our study, 81 giant rectal and perirectal masses, 60 of which were malignant and 21 were benign, were detected. The mean longest diameter was $86 \pm 32 \mathrm{~mm}$ (range: $50-208 \mathrm{~mm}$ ) in malignant masses and $66 \pm 15$ $\mathrm{mm}$ (range: $50-110 \mathrm{~mm}$ ) in benign masses. Malignant masses $(n=60)$ included 48 rectal adenocarcinomas, two prostate adenocarcinomas, three leiomyosarcomas, three ovarian cancers, and four rectal GISTs. Benign mass group $(n=21)$ consisted of two ovarian fibromas, five mature teratomas, five leiomyomas, three perirectal abscesses, two ovarian cystadenomas and four endometriomas. Most of the malignant

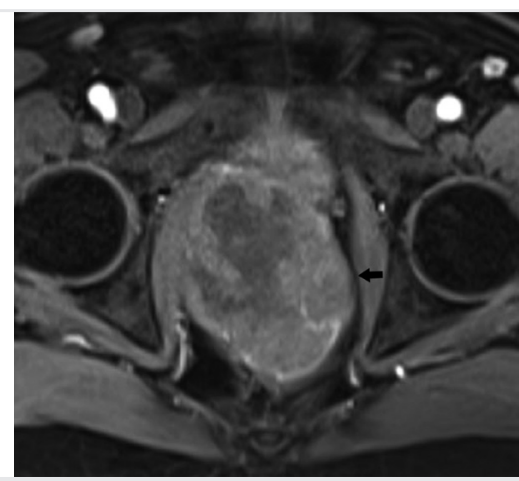

Figure 1: Rectal GIST (arrow) with regular contours and heterogeneous peripheral contrast enhancement in arterial phase. 
masses (47/60, 78\%) had irregular contours. All benign masses (20/21, $95 \%)$ except one perirectal abscess had regular contours. All rectal GISTs $(n=4)$ had regular peripheral contours and mild heterogeneous contrast enhancement beginning in the arterial phase (Figure 1). Unlike other malignant tumors $(n=56)$, heterogeneous, iso-hyperintensity was observed in central sections in T2-weighted sequences of all rectal GISTS $(n=4)$, whereas hypointense signal characteristics were detected in peripheral sections (Figure $2 \mathrm{a}, \mathrm{b})$. Peripheral marked diffusion restriction was present in rectal GISTs (Figure $2 \mathrm{c}$,d). Most rectal adenocarcinomas (41/48, 85\%) had intense enhancement. Lymphadenopathy (43/60, 71\%), adjacent organ invasion (28/60, 46\%) and distant metastasis (16/60, 26\%) were observed only in malignant masses. Significant statistical difference was found between the benign and malignant groups in terms of signal intensities in T1- and T2-weighted sequences $(p<0.05)$. Table 1 shows the distribution of benign and malignant masses according to qualitative MRI characteristics.

The mean ADC values and ratios were significantly lower in malignant masses than benign masses $(p<0.05)$. Table 2 summarizes the quantitative DWI findings of benign and malignant masses. In giant rectal adenocarcinomas $(\mathrm{n}=48)$, the mean $\mathrm{ADC}$ value was $0.87 \pm 0.16 \times 10^{-3} \mathrm{~mm}^{2} / \mathrm{s}$ and the $\mathrm{ADC}$ ratio was $0.57 \pm 0.10$ (Figure $3 \mathrm{a}, \mathrm{b}, \mathrm{c}$ ). The mean $\mathrm{ADC}$ value of mucinous rectal adenocarcinomas $(4 / 48)$ was $0.98 \pm 0.25 \times 10^{-3} \mathrm{~mm}^{2} / \mathrm{s}$. In non-mucinous rectal adenocarcinomas (44/48), the mean $A D C$ value was found to be low with $0.86 \pm 0.15 \times 10^{-3} \mathrm{~mm}^{2} / \mathrm{s}$ and was close to the $A D C$ value of mucinous rectal adenocarcinomas. Rectal GISTs, leiomyosarcomas, prostate cancers,
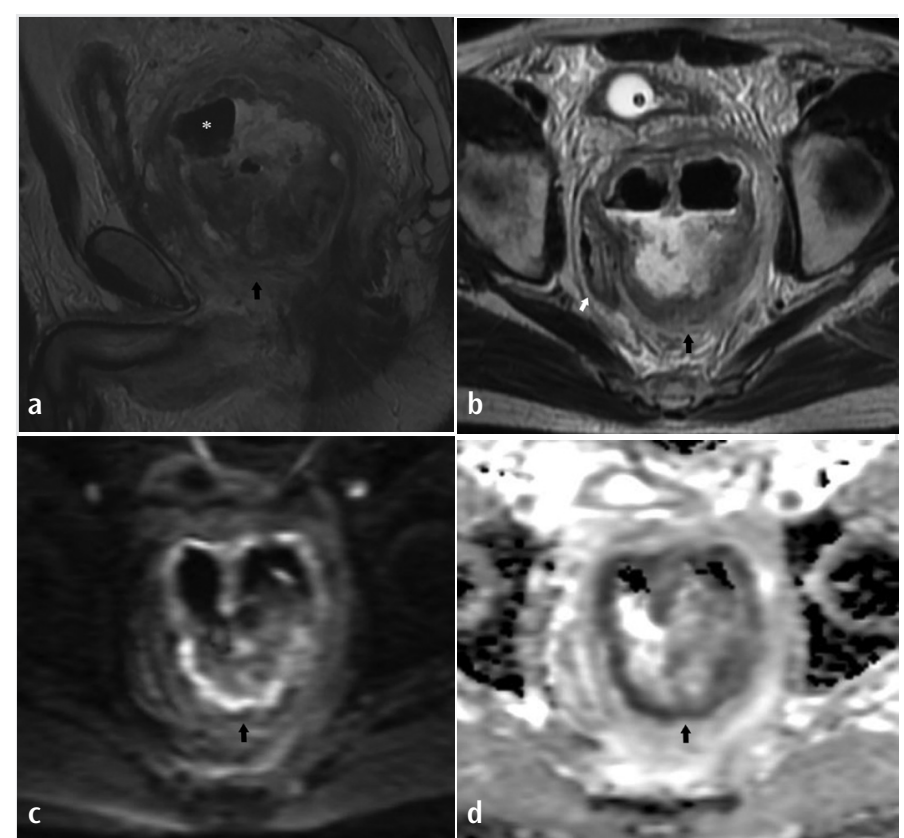

Figure 2a: Air (*) inside the ulcerated rectal GIST (black arrow) which shows peripheral hypo-intensity and heterogeneous central hyper-intensity on sagittal T2-weighted sequence.

Figure 2b: Rectal GIST (black arrow) originated from left anterolateral wall of rectum (white arrow) and showed regular contours, heterogeneous central hyper-intensity and peripheral hypo-intensity on axial T2-weighted sequence.

Figure 2c: Peripheral hyper-intensity (black arrow) and diffusion restriction in rectal GIST on DWI.

Figure 2d: Peripheral hypo-intensity (black arrow) and diffusion restriction in rectal GIST on ADC map. and ovarian cancers yielded low ADC values $\left(0.83 \pm 0.07 \times 10^{-3} \mathrm{~mm}^{2} / \mathrm{s}\right.$, $0.60 \pm 0.08 \times 10^{-3} \mathrm{~mm}^{2} / \mathrm{s}, \quad 0,52 \pm 0.16 \times 10^{-3} \mathrm{~mm}^{2} / \mathrm{s}$, and $0.77 \pm 0.15 \times 10$ $3 \mathrm{~mm}^{2} / \mathrm{s}$, respectively) and $A D C$ ratios were obtained in $(0.53 \pm 0.06$, $0.45 \pm 0.05,0.41 \pm 0.09$, and $0.54 \pm 0.05$, respectively) (Figure $4 \mathrm{a}, \mathrm{b}, \mathrm{c}$ ).
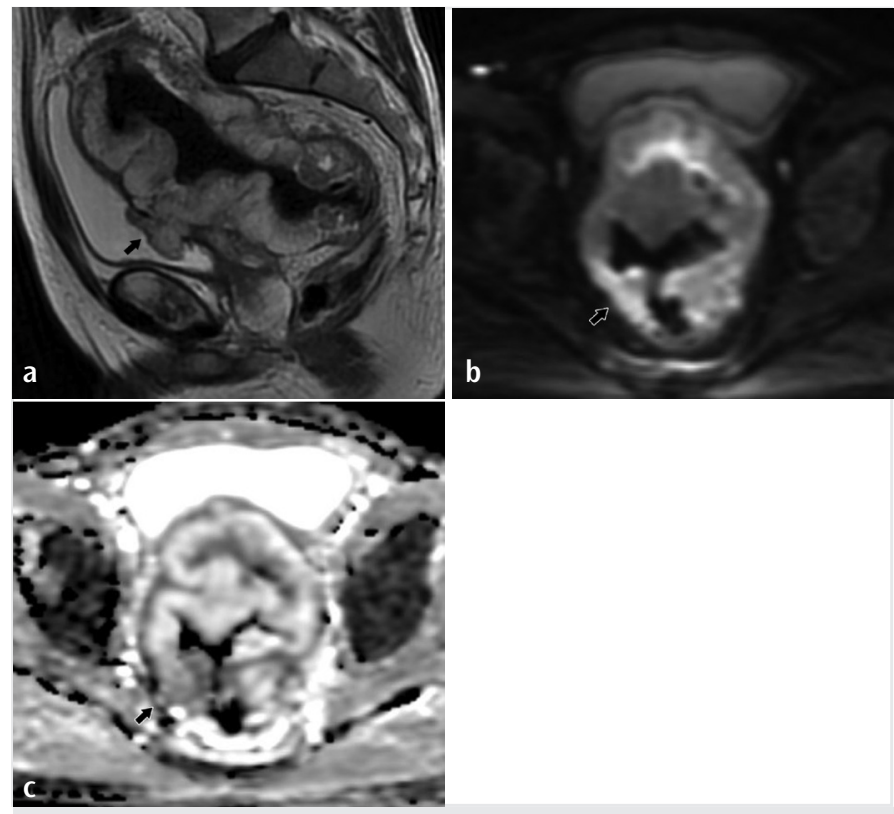

Figure 3a: Giant rectal adenocarcinoma with bladder invasion (black arrow) and hyper-intensity on sagittal T2-weighted sequence.

Figure 3b: Giant rectal adenocarcinoma with peripheral hyper-intense focal areas (black arrow) on DWI.

Figure 3c: Diffusion restriction of giant rectal adenocarcinoma with peripheral hypo-intense focal areas (black arrow) on ADC map.
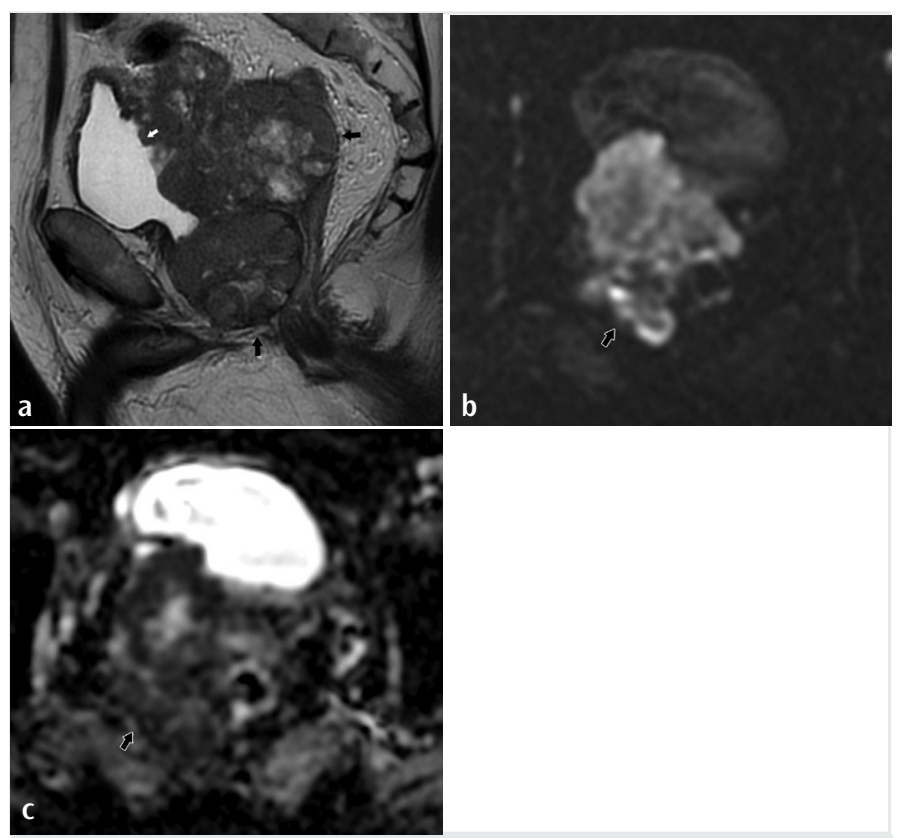

Figure 4a: Giant prostate adenocarcinoma (black arrow) with invasion of rectum (black arrow) and bladder (white arrow) on sagittal T2-weighted sequence.

Figure 4b: Giant prostate adenocarcinoma (black arrow) with irregular contours and hyper-intensity on DWI.

Figure 4c: Diffusion restriction of giant prostate adenocarcinoma (black arrow) with hypo-intensity on ADC map. 


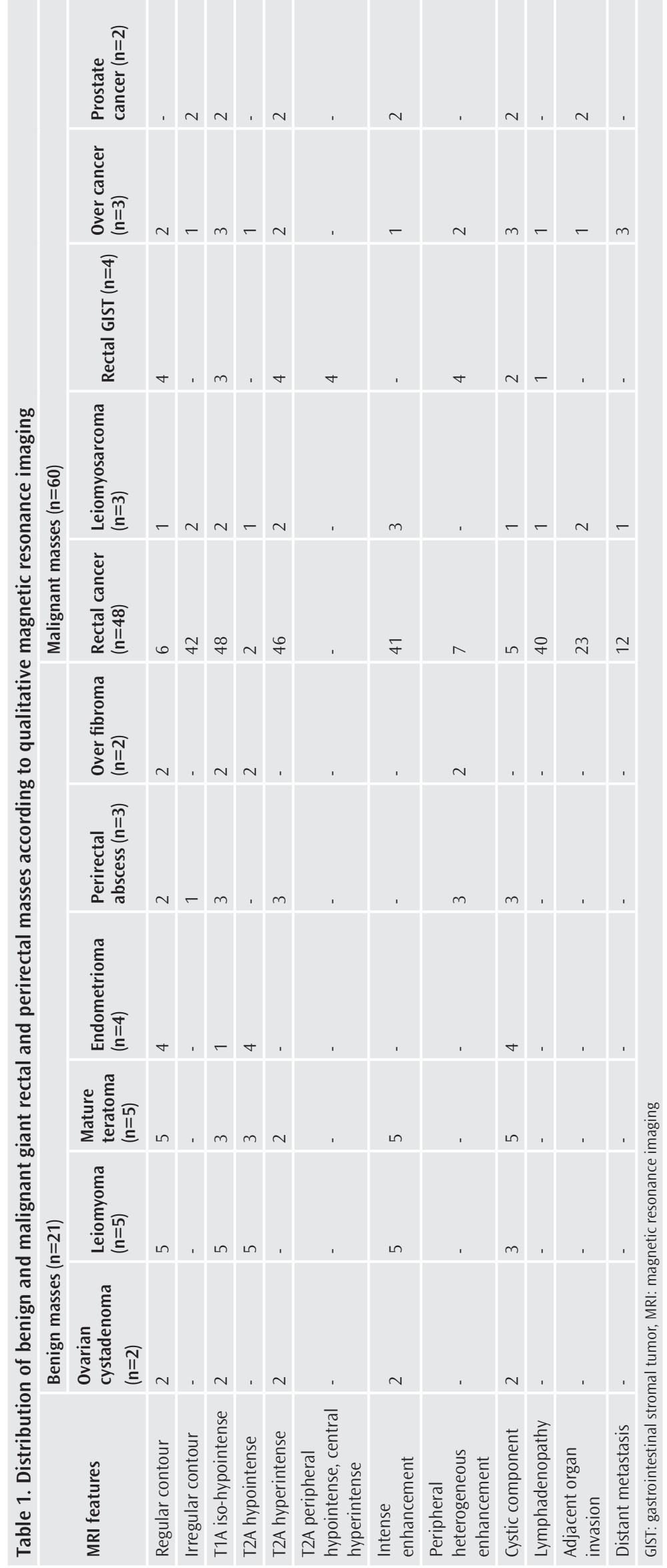

\section{Discussion}

Differential diagnosis of giant rectal and perirectal tumors can be difficult in pre-operative imaging and sometimes even in histopathological evaluation. Therefore, taking into account some specific findings, evaluating pre-operative MRI and DWI findings in detail may help in making the correct diagnosis and deciding the appropriate treatment method (2,4,11-13). DWI is a an imaging modality showing the movement of water in the tissue (8-10). The ADC map is generated from DWI and allows us to detect and measure diffusion restriction. Increased cellularity leads to diffusion restriction (8-10). Diffusion restriction is hyperintense on DWI and hypointense on ADC map (8-10). In addition, $A D C$ value provides us the quantification of diffusion and can be helpful in the differential diagnosis of benign and malignant tumors (8-10).

There are many studies in the literature regarding the efficacy of MRI and DWI in the diagnosis and post-treatment evaluation of rectal cancer. In a study by Li et al. (11), when compared with conventional MRI (71.42\%), combined use of MRI (92.85\%) and DWI (b value: $1000 \mathrm{~s} / \mathrm{mm}^{2}$ ) in patients with rectal adenocarcinoma $(n=84)$ was observed to significantly increase diagnostic accuracy. In another study, Gu et al. (14) evaluated DWI (b value: $1000 \mathrm{~s} / \mathrm{mm}^{2}$ ) and positron emission tomography (PET) CT findings in 33 patients with rectal adenocarcinoma. A significant negative correlation was found between $A D C$ that shows increased tumor cell number and standard uptake value that shows metabolic activity, and a positive correlation was detected between total diffusion index and total lesion glycolysis (14). Çolakoğlu and Erden (15) evaluated the findings of DWI (b value: $1000 \mathrm{~s} / \mathrm{mm}^{2}$ ) in mucinous $(\mathrm{n}=18)$ and non-mucinous $(n=44)$ rectal adenocarcinomas. Diffusion properties and ADC values of mucinous and non-mucinous adenocarcinomas were found to be different (15). In mucinous adenocarcinomas $\left(1.631 \pm 0.375 \times 10^{-3} \mathrm{~mm}^{2} / \mathrm{s}\right)$, higher ADC values were obtained compared to non-mucinous adenocarcinomas $(0.921 \pm 0.157 \times 10$. $3 \mathrm{~mm}^{2} / \mathrm{s}$ ), and a threshold value of $1.27 \times 10^{-3} \mathrm{~mm}^{2} / \mathrm{s}$ was calculated with high sensitivity (94.4\%) and specificity (94.4\%) (15). In a similar study, Nasu et al. (16) investigated the DWI (b value: $\left.1500 \mathrm{~s} / \mathrm{mm}^{2}\right)$ and $A D C$ characteristics of mucinous ( $\left.n=15\right)$ and tubular $(\mathrm{n}=66)$ rectal adenocarcinomas. A higher ADC value was detected in mucinous adenocarcinomas $(1.49 \pm 0.34 \times 10$ $\left.3 \mathrm{~mm}^{2} / \mathrm{s}\right)$ than tubular adenocarcinomas $\left(0.80 \pm 0.15 \times 10^{-3}\right.$ $\mathrm{mm}^{2} / \mathrm{s}$ ) (16). In our study, the number of mucinous rectal adenocarcinomas $(n=4)$ was low and the mean ADC value was close to non-mucinous rectal adenocarcinomas $(n=44)$. In another study, Bassaneze et al. (17) calculated the mean ADC value before chemotherapy as $1.01 \pm 0.05 \times 10^{-3} \mathrm{~mm}^{2} / \mathrm{s}$ in locally advanced rectal adenocarcinomas $(n=33)$. In our study, low ADC values $\left(0.87 \pm 0.16 \times 10^{-3} \mathrm{~mm}^{2} / \mathrm{s}\right)$ were obtained in giant rectal adenocarcinomas $(n=48)$. In addition, the $A D C$ ratio was calculated in our study and not only rectal adenocarcinomas, but also other rectal and perirectal masses $\geq 5 \mathrm{~cm}$ in size were evaluated. 
Table 2. Quantitative DWIa findings and statistical results in benign and malignant giant rectal and perirectal masses

\begin{tabular}{|c|c|c|c|}
\hline & Benign masses & Malignant masses & $\mathbf{p}^{*}$ \\
\hline Mean $A D C^{b}$ value, $\left(\times 10^{-3} \mathrm{~mm}^{2} / \mathrm{s}\right)$ & $1.49 \pm 0.39$ & $0.84 \pm 0.17$ & $<0.00001$ \\
\hline Mean $\mathrm{ADC}$ ratio ${ }^{\mathrm{c}}$ & $0.95 \pm 0.21$ & $0.56 \pm 0.10$ & $<0.00001$ \\
\hline
\end{tabular}

The degree of DWI is associated with the $b$ value $(9,10)$. At high $b, a$ strong diffusion effect and diffusion restriction are achieved, and the noise signal ratio is reduced $(9,10)$. Therefore, using the appropriate b value is important for image quality and accurate evaluation $(9,10)$. Chen et al. (18) used 10 different b values ranging from 0 to $2000 \mathrm{~s} / \mathrm{mm}^{2}$ in the evaluation of rectal cancers by DWI. The most suitable b value combination was found to be 0 and $1000 \mathrm{~s} / \mathrm{mm}^{2}$ (18). In our study, b values of 0 and $1000 \mathrm{~s} / \mathrm{mm}^{2}$ were used.

In another study, the role of MRI in the differential diagnosis of postoperative rectal cancer recurrence $(n=17)$ and benign lesion $(n=8)$ was investigated (19). It was reported that malignant and benign lesions could be distinguished with high sensitivity (100\%), specificity (91.7\%) and accuracy (96.6\%) rates with a threshold ADC value of $1.21 \times 10^{-3}$ $\mathrm{mm}^{2} / \mathrm{s}(19)$. In the dynamic contrast test, the time-intensity curve has also been reported to have a high accuracy rate (92\%) in distinguishing between malignant and benign masses (19). No significant difference was found between the malignant $(2.84 \pm 1.52)$ and benign $(2.58 \pm 0.80)$ groups in terms of signal intensity changes in T2-weighted sequences $(p>0.05)$ (19). In contrast, in our study, a significant difference was found between the benign and malignant groups in terms of $\mathrm{T} 1$ - and T2- weighted signal intensities.

In 14 patients with $<5 \mathrm{~cm}$ four rectal GISTs and $>5 \mathrm{~cm} 10$ rectal GISTs, Jiang et al. (20) observed that six of the GISTs were irregularly contoured and 11 showed heterogeneous enhancement on MRI and CT (20). Kim et al. (4) defined the MRI characteristics of rectal GISTs as eccentric mural masses with regular contour, calcification, necrosis or ulceration, that has hypointensity in T1-weighted sequences, iso-hyperintense signaling in T2-weighted sequences and intensely heterogeneous contrast enhancement. In our study, which included fewer rectal GISTs, all rectal GISTs had contours and signal characteristics were similar. However, the enhancement characteristics were heterogeneous but milder. It was thought that GISTs $\geq 5 \mathrm{~cm}$ in our study may be the cause of peripheral heterogeneous mild enhancement. In addition, the hypointense appearance of peripheral sections of rectal GISTs and heterogeneous hyperintense appearance of central sections of T2-weighted sequences was one of the striking findings of our study. However, in our study, low ADC values and ratios were also obtained in rectal GISTs.

There are some limitations of our study. One of them is the retrospective nature of the study with a small number of benign masses. The other is that qualitative and quantitative MRI findings were evaluated by a single radiologist.

\section{Conclusion}

The evaluation of specific MRI characteristics and ADC ratio measurements have an important role in the differential diagnosis of giant rectal and perirectal masses, and guide the planning of patient treatment.

Ethics Committee Approval: University of Health Sciences, Ümraniye Training and Research Hospital Ethics Committee of Clinical Studies, (decision no: 235, date: 23/01/2019).

Informed Consent: Written consent was obtained from the patients.

Peer-review: Externally peer-reviewed.

Author Contributions: Surgical and Medical Practices - F.K., Ö.D.; Concept - F.K., Ö.D.; Design - F.K., Ö.D.; Data Collection and/ or Processing - F.K., Ö.D.; Analysis and/or Interpretation - F.K., Ö.D.; Literature Search F.K., Ö.D.; Writing Manuscript - F.K., Ö.D.

Conflict of Interest: No conflict of interest was declared by the authors

Financial Disclosure: The authors declared that this study received no financial support.

\section{References}

1. Purysko AS, Coppa CP, Kalady MF, Pai RK, Leão Filho HM, Thupili CR, et al. Benign and malignant tumors of the rectum and perirectal region. Abdom Imaging 2014; 39: 824-52.

2. Sangster GP, Ballard DH, Nazar M, Tsai R, Donato M, D’Agostino HB. Multimodality imaging review of anorectal and perirectal diseases with histological, endoscopic, and operative correlation, Part I: Anatomy and neoplasms. Curr Probl Diagn Radiol 2018; 29. pii: S0363-0188(18)30115-4.

3. Valdes-Devesa V, Jimenez MDM, Sanz-Rosa D, Espada Vaquero M, Alvarez Moreno E, Sainz de la Cuesta Abbad R. Preoperative diagnosis of atypical pelvic leiomyoma and sarcoma: the potential role of diffusion-weighted imaging. J Obstet Gynaecol 2018; 12: 1-7.

4. Kim H, Kim JH, Lim JS, Choi JY, Chung YE, Park MS, et al. MRI findings of rectal submucosal tumors. Korean J Radiol 2011; 12: 487-98.

5. Neale JA. Retrorectal tumors. Clin Colon Rectal Surg 2011; 24: 149-60.

6. Kameyama H, Kanda T, Tajima $\mathrm{Y}$, Shimada $\mathrm{Y}$, Ichikawa $\mathrm{H}$, Hanyu $\mathrm{T}$, et al. Management of rectal gastrointestinal stromal tumor. Transl Gastroenterol Hepatol 2018; 3: 8.

7. Maddah G, Abdollahi A, Etemadrezaie H, Ganjeifar B, Gohari B, Abdollahi $\mathrm{M}$, et al. Problems in Diagnosis and Treatment of Retrorectal Tumors: Our Experience in 50 Patients. Acta Med Iran 2016; 54: 644-50.

8. Koc Z, Erbay G, Karadeli E. Internal comparison standard for abdominal diffusion-weighted imaging. ActaRadiol 2017; 58: 1029-36.

9. Koh DM, Collins DJ. Diffusion-weighted MRI in the body: applications and challenges in oncology. AJR Am J Roentgenol 2007; 188: 1622-35. 
10. Dietrich 0, Biffar A, Baur-Melnyk A, Reiser MF. Technical aspects of MR diffusion imaging of the body. Eur J Radiol 2010; 76: 314-22.

11. Li F, Zhang W, Li J, Zhu X, Chen H, Wu Y, et al. The clinical application value of MR diffusion-weighted imaging in the diagnosis of rectal cancer: $A$ retrospective study. Medicine (Baltimore). 2018; 97: e13732.

12. Curvo-Semedo L, Lambregts DM, Maas M, Beets GL, Caseiro-Alves F, Beets-Tan RG. Diffusion-weighted MRI in rectal cancer: apparent diffusion coefficient as a potential noninvasive marker of tumor aggressiveness. J Magn Reson Imaging 2012; 35: 1365-71.

13. Santos P, Cunha TM. Uterine sarcomas: clinical presentation and MRI features. Diagn Interv Radiol 2015; 21: 4-9.

14. Gu J, Khong PL, Wang S, Chan Q, Law W, Zhang J. Quantitative assessment of diffusion-weighted MR imaging in patients with primary rectal cancer: correlation with FDG-PET/CT. Mol Imaging Biol 2011; 13: 1020-8.

15. Çolakoğlu Er H, Erden A. Mean ADC values discriminate rectal mucinous carcinoma from rectal nonmucinous adenocarcinoma. Turk J Med Sci 2017; 47: 1520-5.
16. Nasu K, Kuroki Y, Minami M. Diffusion-weighted imaging findings of mucinous carcinoma arising in the ano-rectal region: comparison of apparent diffusion coefficient with that of tubular adenocarcinoma. Jpn J Radiol 2012; 30: 120-7.

17. Bassaneze T, Gonçalves JE, Faria JF, Palma RT, Waisberg J. Quantitative aspects of diffusion-weighted magnetic resonance imaging in rectal cancer Response to neoadjuvant therapy. Radiol Oncol 2017; 51: 270-6.

18. Chen L, Shen F, Li Z, Lu H, Chen Y, Wang Z, et al. Diffusion-weighted imaging of rectal cancer on repeatability and cancer characterization: an effect of b-value distribution study. Cancer Imaging 2018; 18: 43.

19. Wang LL, Duan Q, Xue YQ, Huang XM, Wang CS, Sun B. Differentiation of recurrence rectal cancer and benign pelvic lesions after curative rectal operation with 3.0 T magnetic resonance. Zhonghua Wei Chang Wai Ke Za Zhi 2011; 14: 859-63.

20. Jiang ZX, Zhang SJ, Peng WJ, Yu BH. Rectal gastrointestinal stromal tumors: imaging features with clinical and pathological correlation. World J Gastroenterol 2013; 19: 3108-16. 